\title{
IgA vasculitis or Henoch-Schönlein purpura: genetics and beyond
}

\author{
Marija Jelusic $^{1}$ (D) $\cdot$ Mario Sestan ${ }^{1}$ \\ Received: 17 January 2021 / Accepted: 4 February 2021 / Published online: 16 February 2021 \\ (C) IPNA 2021
}

\section{Introduction}

Considering the fact that the IgA vasculitis (IgAV), formerly known as Henoch-Schönlein purpura, is the most common systemic vasculitis in childhood, with an incidence fluctuating from 3 to 27 cases per 100000 children [1, 2], it would be expected that there are uniform guidelines for diagnosis and treatment of this clinical entity and that we know a lot about the etiopathogenesis of the disease. However, everyday clinical practice confronts us with many unanswered questions and dilemmas concerning IgAV disease severity, duration of the autoimmune process, optimal treatment choices, and prognosis, and all of them arise from insufficient knowledge of the mechanisms of disease development.

The main attribute of IgAV is palpable purpura which affects the lower extremities and buttocks [3]. Because in most cases the disease is self-limiting and has an excellent prognosis, these patients usually receive attention when complications occur, both acute, which are predominantly related to gastrointestinal system, and chronic, among which the most important is kidney involvement $[4,5]$. Given that nephritis (IgAVN) occurs in 20 to $60 \%$ of children with $\operatorname{IgAV}[1,4]$, of whom 1.6 to $15 \%$ may develop kidney failure $[6,7]$, this disease is of interest to nephrologists. These data also warn us that the disease should not be underestimated and that it does not always have to be benign.

Therefore, we read with special interest a series of articles by Koskela et al., published in this and previous editions of Pediatric Nephrology, which relate to aspects of the genetic basis of the disease, issues associated with different histological classifications of IgAVN, and selection of appropriate therapy

Marija Jelusic

marija.jelusic@mef.hr

1 Department of Paediatrics, Division of Clinical Immunology, Rheumatology and Allergology, Centre of Reference for Paediatric and Adolescent Rheumatology of Ministry of Health of the Republic Croatia, University of Zagreb School of Medicine, University Hospital Centre Zagreb, Kispaticeva 12, 10000 Zagreb, Croatia
[8-11]. With these papers, the authors nicely concluded the topic of $\operatorname{IgAV}$ while also pointing out the most important unresolved issues related to the disease.

The latest article by Koskela et al. is a genome-wide association study (GWAS) in children with IgAV. Although this is neither the first nor the largest study in which GWAS is applied in the same target patient population [12], it brings novelties in the sense that a larger number of patients with IgAVN is included, and it is innovative in that the population of patients with IgAV is not only compared with the general reference population but also with patients with inflammatory bowel disease (IBD). The most important result that emerges from the above study is that haplotype DQA $1 * 01: 01 /$ DQB1 $* 05: 01 / \mathrm{DRB} 1 * 01: 01$ is associated with susceptibility to IgAV but not with other autoimmune diseases.

\section{Results of the latest Koskela et al.'s study}

The authors conducted a retrospective study with a wellcharacterized study group of 46 patients with childhoodonset IgAV, who fulfilled the criteria defined by the European League Against Rheumatism (EULAR), Paediatric Rheumatology International Trials Organization (PRINTO), and Paediatric Rheumatology European Society (PRES) [3]. It is important to note that almost all patients with IgAV included in the study developed IgAVN, and the vast majority of patients had undergone a kidney biopsy; hence, the results are with reference to IgAVN. Despite the fact that the sample size for GWAS was very small, biopsy-proven IgAVN in most patients as well as a power analysis provided, according to which the power was $>0.9$ for all analyzed single nucleotide polymorphisms and HLA alleles, support the reliability of the results. The authors also involved 49 children with biopsyproven Crohn's disease and/or orofacial granulomatosis and a large reference population consisting of 18,757 Finnish bone marrow and blood donors, representing the Finnish population. The results of this research can be viewed as confirmatory to those of Lopez-Mejias et al., which pointed to the 
significance of the HLA class II genes with IgAV susceptibility at an intergenic region between $H L A-D Q A 1$ and HLA$D Q B 1$ and reported no significant associations outside the HLA region [12]. HLA alleles linked with increased susceptibility to IgAV were DQA $1 * 01: 01$, DQB $1 * 05: 01$, and DRB1*01:01, while these were protective in patients with IBD. Haplotype DQA1*01:01/DQB1*05:01/DRB1*01:01 differed between IgA patients, IBD patients, and reference population (OR 4.15, 95\% CI 3.18-5.41). The authors did not observe the association of these alleles or the corresponding haplotype with the severity of kidney disease in IgAV. Interestingly, the authors noted that two of these three alleles (DQA $1 * 01: 01, \mathrm{DQB} 1 * 05: 01)$ in previous research have been associated with increased risk for IgA nephropathy (IgAN), which is the clinical entity around which there is controversy over whether it is a disease that is a form of IgAV limited to the kidney in the absence of extrarenal clinical signs $[13,14]$.

\section{Generalizability and future application}

At the moment, our understanding of IgAV is still burdened with various issues, the most important of which are which patients will develop more severe forms of gastrointestinal complications, which patients will develop IgAVN that will progress to kidney failure, and how to optimally treat patients with IgAVN. Since the etiopathogenesis of IgAV is complex and not fully understood, and may involve complex interactions between various environmental and genetic factors, studies investigating the genetic background of the disease were expected to identify candidate genes associated with IgAV susceptibility, particularly IgAVN. However, GWAS have so far indicated the significance of the HLA class II genes $[8,12]$, but, as Koskela et al. have pointed out, potential susceptibility loci to IgAV were not associated with different phenotypes, i.e., IgAVN or severe gastrointestinal complications. Consequently, these GWAS have not provided data on how to predict the course in these patients. Nevertheless, the aforementioned studies showed that IgAV is a prototype of HLA class II disease, thus sharing some features with giant cell arteritis and anti-neutrophil cytoplasmic antibody (ANCA)-associated vasculitis (AAV) $[15,16]$. Unlike in IgAV, GWAS showed that different ANCA specificities within the AAV group have different genetic backgrounds, which could have immunopathogenic and therapeutic implications [17]. Unfortunately, the current results of GWAS in IgAV cannot contribute to the development of individualized treatment strategies for patients with complications of IgAV, i.e., enable the application of precision medicine or planning different concepts of following up patients stratified according to the risk of complications. It is important to note that the main limitation of both GWAS that have investigated IgAV is the small number of IgAV patients. Thus, the study of Lopez-
Mejias et al. included 308 patients diagnosed with IgAV and that of Koskela et al. only 46 patients. In order to overcome this problem, a larger number of patients need to be included in future genetic research on $\operatorname{IgAV}$. One potential problem that arises here is the fragmentation of care for patients with IgAV between nephrologists and rheumatologists [18]. It is therefore important that in the future, similar research is based on the collaboration of both specialties. In addition, populations of patients of different ancestry need to be included, so it is essential that such research is multicentric, since in different populations, there may be a variation in risk allele frequency, as shown by the example of IgAN [19].

IgAN is interesting to mention for several reasons. Although IgAV and IgAN are currently considered different diseases, there are various commonalities and differences between them. From the point of view of genetics, cases of both diseases within the same family are particularly interesting, as well as the possibility that in a pair of identical twins, one can develop IgAVN and the other one IgAN [20, 21]. Koskela et al. noticed that IgAV and IgAN share some common HLA alleles that have been linked with the susceptibility for both diseases. On the other hand, these alleles were protective for the development of IBD. In contrast, in a GWAS conducted by Kyrilluk et al., multiple risk loci for IgAN were identified, most of which were associated with a risk for IBD or are involved in various molecular pathways that could be associated with the pathogenesis of the disease [19]. IgAN has also been observed to be associated with different gene variants to defend the intestinal mucosa from various pathogens, particularly parasitic infections. This explains the occurrence of IgAN hotspots in some parts of the world, for example, in Asia, where there is an overlap of genetic and environmental factors, since this part of the world has the highest global burden of soil-transmitted helminths infections and the risk alleles for IgAN in that population may represent an adaptation to the invasion of intestinal pathogens [19]. Considering that it is known that in IgAV various infections are often triggers for the development of the disease, it would be interesting to investigate whether similar observations apply in IgAV. This question can be viewed in the context of the latest research investigating the spatial distribution of IgAV applying modern geostatistical methods, according to which the linear clustering of IgAVN in the eastern part of Croatia follows the course of the Drava and, partially Danube, rivers [2]. From the nephrological aspect, intriguing is the fact that in the vicinity of these locations are areas of Balkan endemic nephropathy. Notwithstanding that hotspot clusters of disease occur in areas where there is substantial overlap of genetic and environmental influences, in different proportions, it would be interesting to investigate whether there are potential susceptibility loci in this group of patients. Such hotspots appear to be present in other parts of the world as the incidence of IgAV varies depending on geographical area, and from the 
research, it is also evident that the prevalence of nephritis in patients with IgAV is quite wide, depending on individual studies and countries where they have been implemented [1, 2]. The geospatial distribution of gene risk has been demonstrated in IgAN, in such a way that the risk of developing the disease increases with Eastward and Northward distance from Africa [22]. These observations were explained by polygenic adaptation to local environments. The authors of this research also investigated genetic risk with different environmental factors, such as climate, pathogen load, and dietary factors, and found that genetic risk is linked with climatic and dietary factors, and especially with local pathogen diversity, among which the strongest association was observed for helminth diversity. Similar studies in IgAV do not currently exist.

So far, only two GWAS of IgAV have been conducted, and neither has detected potential susceptibility loci to IgAV outside HLA class II genes that reached the genome-wide level of significance $[8,12]$. Howbeit, previous studies have shown that variants in various non-HLA genes associated with immune and inflammatory response (such as genes for cytokines, chemokines, adhesion molecules, $\mathrm{T}$ lymphocytes, and nitric oxide production) may also have significance in the etiopathogenesis of IgAV [23]. Some of these could be associated with different disease phenotypes. In this regard, cytokine gene polymorphisms should be mentioned. Thus, it was found that interleukin 1 receptor antagonist gene polymorphism was related to severe and kidney involvement in patients with IgAV, but with no influence on susceptibility [24], while interleukin 8 gene polymorphism was found in patients with IgAVN [25]. On the other hand, polymorphisms of the renin-angiotensin system were linked to a higher IgAV prevalence [26]. Although the results of these studies provide more insight into the various molecular pathways that could be targeted sites of action of potential new medicines, they are mostly small studies, and the results in terms of the potential association with IgAV do not indicate such a strong connection as is the case with HLA genes.

It is important to emphasize that genomic analyses represent only one level by which the mechanism of disease development is revealed. Today it is clear that the influence of genetics alone cannot explain the entirety of the risk of vasculitis, including IgAV. At the crossroads of genetic and environmental effects on the pathogenesis of IgAV, there are epigenetic mechanisms that regulate gene activity and expression, with an impact on disease phenotype. A genome-wide excessive $\mathrm{H} 3$ acetylation and $\mathrm{H} 3 \mathrm{~K} 4$ methylation have been demonstrated in peripheral blood mononuclear cells of patients with IgAVN accompanied by positive correlation with disease activity [27]. In CD4+ T cells of patients with IgAV, $\mathrm{H} 3$ acetylation and $\mathrm{H} 3 \mathrm{~K} 4$ methylation are increased in promoter and enhancer regions of interleukin 4 , which is a Th2 cytokine, suggesting a role of Th2 cells in the pathogenesis of $\operatorname{IgAV}[27]$.
Since differential gene expression plays an important role in the onset and progression of the disease, at the level of mRNA and protein, a combined approach is needed to better understand the mechanism of onset of the disease, with integration of different "omics" techniques, including proteomics and transcriptomics [28]. Thanks to the use of proteomics, especially targeted proteomics, promising biomarkers can be identified, which can help stratify patients with respect to the risk of developing kidney disease progression and may contribute to the earlier diagnosis of kidney disease [29, 30]. The combined approach, in terms of the integration of transcriptomics and proteomics, reveals new molecular pathways and mechanisms of kidney disease progression in $\operatorname{IgAV}$, which represent potential clues for the development of new therapeutic approaches [28].

\section{Conclusion}

The study by Koskela et al. confirms that the only potential susceptibility loci to IgAV that reached the genomewide level of significance were specific HLA region II alleles. Haplotype DQA1*01:01/DQB1*05:01/ DRB1*01:01 was linked with susceptibility to IgAV only, but not with other autoimmune diseases, and it was not associated with different clinical manifestations of IgAV. Listed HLA alleles were protective in patients with IBD. This research represents the largest GWAS to date in patients with IgAVN, and although the total number of patients included was small, the power analysis conducted suggests that the result is reliable. Future studies with a larger number of patients, based on an integrative approach, combining genomics, proteomics, transcriptomics, and epigenetics, will play an important role in discovering the mechanisms of IgAV and IgAVN onset and progression, and thus in finding new therapeutic options, in addition to genetic analyses.

Code availability Not applicable.

Data Availability Not applicable.

\section{Declarations}

Ethics approval Not applicable.

Consent to participate Not applicable.

Consent for publication Not applicable.

Conflict of interest The authors declare no competing interests. 


\section{References}

1. Gardner-Medwin JM, Dolezalova P, Cummins C, Southwood TR (2002) Incidence of Henoch-Schonlein purpura, Kawasaki disease, and rare vasculitides in children of different ethnic origins. Lancet 360:1197-1202

2. Sapina M, Frkovic M, Sestan M, Srsen S, Ovuka A, Batnozic Varga M, Kramaric K, Brdaric D, Milas K, Gagro A, Jelusic M (2020) Geospatial clustering of childhood IgA vasculitis and IgA vasculitis-associated nephritis. Ann Rheum Dis. https://doi.org/10. 1136/annrheumdis-2020-218649

3. Ozen S, Pistorio A, Iusan SM, Bakkaloglu A, Herlin T, Brik R, Buoncompagni A, Lazar C, Bilge I, Uziel Y, Rigante D, Cantarini L, Hilario MO, Silva CA, Alegria M, Norambuena X, Belot A, Berkun Y, Estrella AI, Olivieri AN, Alpigiani MG, Rumba I, Sztajnbok F, Tambic-Bukovac L, Breda L, Al-Mayouf S, Mihaylova D, Chasnyk V, Sengler C, Klein-Gitelman M, Djeddi D, Nuno L, Pruunsild C, Brunner J, Kondi A, Pagava K, Pederzoli S, Martini A, Ruperto N, Paediatric Rheumatology International Trials Organisation (PRINTO) (2010) EULAR/PRINTO/PRES criteria for Henoch-Schonlein purpura, childhood polyarteritis nodosa, childhood Wegener granulomatosis and childhood Takayasu arteritis: Ankara 2008. part II: Final classification criteria. Ann Rheum Dis 69:798-806

4. Reid-Adam J (2014) Henoch-Schonlein purpura. Pediatr Rev 35: 447-449

5. Davin JC, Coppo R (2014) Henoch-Schönlein purpura nephritis in children. Nat Rev Nephrol 10:563-573

6. Ronkainen J, Nuutinen M, Koskimies O (2002) The adult kidney 24 years after childhood Henoch-Schonlein purpura: a retrospective cohort study. Lancet 360:666-670

7. Narchi H (2005) Risk of long term renal impairment and duration of follow up recommended for Henoch-Schonlein purpura with normal or minimal urinary findings: a systematic review. Arch Dis Child 90:916-920

8. Koskela M, Nihtilä J, Ylinen E, Kolho K-L, Nuutinen M, Ritari M, Jahnukainen T (2020) HLA-DQ and HLA-DRB1 alleles associated with Henoch-Schönlein purpura nephritis in Finnish pediatric population: a genome-wide association study. Pediatr Nephrol. https:// doi.org/10.1007/s00467-021-04955-7

9. Koskela M, Ylinen E, Autio-Harmainen H, Tokola H, Heikkilä P, Lohi J, Jalanko H, Nuutinen M, Jahnukainen T (2019) Prediction of renal outcome in Henoch-Schönlein nephritis based on biopsy findings. Pediatr Nephrol 35:659-668

10. Koskela M, Jahnukainen T, Endén K, Arikoski P, Kataja J, Nuutinen M, Ylinen E (2019) Methylprednisolone or cyclosporine a in the treatment of Henoch-Schönlein nephritis: a nationwide study. Pediatr Nephrol 34:1447-1456

11. Koskela M, Ylinen E, Ukonmaanaho EM, Autio-Harmainen H, Heikkilä P, Lohi J, Jauhola O, Ronkainen J, Jahnukainen T, Nuutinen M (2017) The ISKDC classification and a new semiquantitative classification for predicting outcomes of Henoch-Schönlein purpura nephritis. Pediatr Nephrol 32:1201-1209

12. Lopez-Mejias R, Carmona FD, Castaneda S, Genre F, RemuzgoMartinez S, Sevilla-Perez B, Ortego-Centeno N, Llorca J, Ubilla B, Mijares V, Pina T, Miranda-Filloy JA, Navas Parejo A, de Argila D, Aragues M, Rubio E, Luque ML, Blanco-Madrigal JM, GalindezAguirregoikoa E, Jayne D, Blanco R, Martin J, Gonzalez-Gay MA (2017) A genome-wide association study suggests the HLA class II region as the major susceptibility locus for IgA vasculitis. Sci Rep 7:5088-017-03915-2

13. Davin JC, Ten Berge IJ, Weening JJ (2001) What is the difference between IgA nephropathy and Henoch-Schönlein purpura nephritis? Kidney Int 59:823-834
14. Davin JC, Coppo R (2013) Pitfalls in recommending evidencebased guidelines for a protean disease like Henoch-Schönlein purpura nephritis. Pediatr Nephrol 28:1897-1903

15. Carmona FD, Mackie SL, Martín JE, Taylor JC, Vaglio A, Eyre S, Bossini-Castillo L, Castañeda S, Cid MC, Hernández-Rodríguez J, Prieto-González S, Solans R, Ramentol-Sintas M, GonzálezEscribano MF, Ortiz-Fernández L, Morado IC, Narváez J, Miranda-Filloy JA, Spanish GCA Group, Beretta L, Lunardi C, Cimmino MA, Gianfreda D, Santilli D, Ramirez GA, Soriano A, Muratore F, Pazzola G, Addimanda O, Wijmenga C, Witte T, Schirmer JH, Moosig F, Schönau V, Franke A, Palm Ø, Molberg Ø, Diamantopoulos AP, Carette S, Cuthbertson D, Forbess LJ, Hoffman GS, Khalidi NA, Koening CL, Langford CA, McAlear CA, Moreland L, Monach PA, Pagnoux C, Seo P, Spiera R, Sreih AG, Warrington KJ, Ytterberg SR, Gregersen PK, Pease CT, Gough A, Green M, Hordon L, Jarrett S, Watts R, Levy S, Patel Y, Kamath S, Dasgupta B, Worthington J, Koeleman BP, de Bakker PI, Barrett JH, Salvarani C, Merkel PA, González-Gay MA, Morgan AW, Martín J (2015) A large-scale genetic analysis reveals a strong contribution of the HLA class II region to giant cell arteritis susceptibility. Am J Hum Genet 96:565-580

16. Robson KJ, Ooi JD, Holdsworth SR, Rossjohn J, Kitching AR (2018) HLA and kidney disease: from associations to mechanisms. Nat Rev Nephrol 14:636-655

17. Lyons PA, Rayner TF, Trivedi S, Holle JU, Watts RA, Jayne DR, Baslund B, Brenchley P, Bruchfeld A, Chaudhry AN, Cohen Tervaert JW, Deloukas P, Feighery C, Gross WL, Guillevin L, Gunnarsson I, Harper L, Hrušková Z, Little MA, Martorana D, Neumann T, Ohlsson S, Padmanabhan S, Pusey CD, Salama AD, Sanders JS, Savage CO, Segelmark M, Stegeman CA, Tesař V, Vaglio A, Wieczorek S, Wilde B, Zwerina J, Rees AJ, Clayton DG, Smith KG (2012) Genetically distinct subsets within ANCAassociated vasculitis. N Engl J Med 367:214-223

18. Jelusic M, Sestan M, Cimaz R, Ozen S (2019) Different histological classifications for Henoch-Schönlein purpura nephritis: which one should be used? Pediatr Rheumatol Online J 17:10

19. Kiryluk K, Li Y, Scolari F, Sanna-Cherchi S, Choi M, Verbitsky M, Fasel D, Lata S, Prakash S, Shapiro S, Fischman C, Snyder HJ, Appel G, Izzi C, Viola BF, Dallera N, Del Vecchio L, Barlassina C, Salvi E, Bertinetto FE, Amoroso A, Savoldi S, Rocchietti M, Amore A, Peruzzi L, Coppo R, Salvadori M, Ravani P, Magistroni R, Ghiggeri GM, Caridi G, Bodria M, Lugani F, Allegri L, Delsante M, Maiorana M, Magnano A, Frasca G, Boer E, Boscutti G, Ponticelli C, Mignani R, Marcantoni C, Di Landro D, Santoro D, Pani A, Polci R, Feriozzi S, Chicca S, Galliani M, Gigante M, Gesualdo L, Zamboli P, Battaglia GG, Garozzo M, Maixnerova D, Tesar V, Eitner F, Rauen T, Floege J, Kovacs T, Nagy J, Mucha K, Paczek L, Zaniew M, Mizerska-Wasiak M, Roszkowska-Blaim M, Pawlaczyk K, Gale D, Barratt J, Thibaudin L, Berthoux F, Canaud G, Boland A, Metzger M, Panzer U, Suzuki H, Goto S, Narita I, Caliskan Y, Xie J, Hou P, Chen N, Zhang H, Wyatt RJ, Novak J, Julian BA, Feehally J, Stengel B, Cusi D, Lifton RP, Gharavi AG (2014) Discovery of new risk loci for IgA nephropathy implicates genes involved in immunity against intestinal pathogens. Nat Genet 46:1187-1196

20. Levy M (2001) Familial cases of Berger's disease and anaphylactoid purpura. Kidney Int 60:1611-1612

21. Meadow SR, Scott DG (1985) Berger disease: Henoch-Schönlein without the rash. J Pediatr 106:27-32

22. Kiryluk K, Li Y, Sanna-Cherchi S, Rohanizadegan M, Suzuki H, Eitner F, Snyder HJ, Choi M, Hou P, Scolari F, Izzi C, Gigante M, Gesualdo L, Savoldi S, Amoroso A, Cusi D, Zamboli P, Julian BA, Novak J, Wyatt RJ, Mucha K, Perola M, Kristiansson K, Viktorin A, Magnusson PK, Thorleifsson G, Thorsteinsdottir U, Stefansson K, Boland A, Metzger M, Thibaudin L, Wanner C, Jager KJ, Goto S, Maixnerova D, Karnib HH, Nagy J, Panzer U, Xie J, Chen N, 
Tesar V, Narita I, Berthoux F, Floege J, Stengel B, Zhang H, Lifton RP, Gharavi AG (2012) Geographic differences in genetic susceptibility to IgA nephropathy: GWAS replication study and geospatial risk analysis. PLoS Genet 8:e1002765

23. López-Mejías R, Castañeda S, Genre F, Remuzgo-Martínez S, Carmona FD, Llorca J, Blanco R, Martín J, González-Gay MA (2018) Genetics of immunoglobulin-A vasculitis (HenochSchönlein purpura): an updated review. Autoimmun Rev 17:301315

24. Amoli MM, Thomson W, Hajeer AH, Calviño MC, Garcia-Porrua C, Ollier WE, Gonzalez-Gay MA (2002) Interleukin 1 receptor antagonist gene polymorphism is associated with severe renal involvement and renal sequelae in Henoch-Schönlein purpura. J Rheumatol 29:1404-1407

25. Tabel Y, Mir S, Berdeli A (2012) Interleukin 8 gene 2767 A/G polymorphism is associated with increased risk of nephritis in children with Henoch-Schönlein purpura. Rheumatol Int 32:941-947

26. Ozkaya O, Söylemezoğlu O, Gönen S, Misirlioğlu M, Tuncer S, Kalman S, Buyan N, Hasanoğlu E (2006) Renin-angiotensin system gene polymorphisms: association with susceptibility to
Henoch-Schonlein purpura and renal involvement. Clin Rheumatol 25:861-865

27. Luo S, Liang G, Zhang P, Zhao M, Lu Q (2013) Aberrant histone modifications in peripheral blood mononuclear cells from patients with Henoch-Schönlein purpura. Clin Immunol 146:165-175

28. Xie B, Zhang W, Zhang Q, Zhang Q, Wang Y, Sun L, Liu M, Zhou $\mathrm{P}(2020)$ An integrated transcriptomic and proteomic analysis identifies significant novel pathways for Henoch-Schönlein purpura nephritis progression. Biomed Res Int 2020:2489175

29. Fang X, Wu H, Lu M, Cao Y, Wang R, Wang M, Gao C, Xia Z (2020) Urinary proteomics of Henoch-Schönlein purpura nephritis in children using liquid chromatography-tandem mass spectrometry. Clin Proteomics 17:10

30. Demir S, Kaplan O, Celebier M, Sag E, Bilginer Y, Lay I, Ozen S (2020) Predictive biomarkers of IgA vasculitis with nephritis by metabolomic analysis. Semin Arthritis Rheum 50:1238-1244

Publisher's Note Springer Nature remains neutral with regard to jurisdictional claims in published maps and institutional affiliations. 